\title{
Perlindungan Hukum bagi Dosen sebagai Tenaga Pendidik untuk Memperoleh Hak Ketenagakerjaanya
}

\author{
Ilmal Yaqin \\ Faculty of Law, Proklamasi 45 University of Yogyakarta \\ ilmal84@yahoo.co.id
}

Submitted: 2016-11-14; Reviewed: 2017-05-05; Accepted: 2017-06-06

\begin{abstract}
Legal protection for all workers/employees, especially for lecturers working under foundation, is absolutely necessary, since there are still many cases involving the university and the foundation. These problems still continue to haunt lecturers, so it needs concerted effort to minimize existing problems. Although there are regulations governing the relations between workers/employees with employers, but in a practical level is still not fully implemented. It is associated with several problems, one of which is the position of lecturers at the level of subordinate more than the foundation. The phenomenon wont be occured when educators take the advantage of legal protection that already regulated by legislation. This study will elaborate on legal protection for the workers, especially for educators. The research method is a normative juridical approach using approach legislation. The results are legal protections for educators stipulated in Law No. 21 Year 2000 on the labor Unions, in particular regarding the purpose of the establishment of labor unions. In addition, Law No. 13 of 2003 on Employment already protect workers/employees, including educators, namely through union/employee.
\end{abstract}

Keywords: educators; employment; legal protection; labor union

\section{PENDAHULUAN}

Indonesia

merupakan

negara

berkembang yang berusaha meningkatkan pembangunan disegala bidang kehidupan, salah satunya adalah pembangunan dalam bidang ekonomi dan pendidikan. Pembangunan dalam bidang ekonomi dan pendidikan sangat penting karena merupakan salah satu faktor penunjang terwujudnya pembangunan nasional yang mengarah pada peningkatkan kesejahteraan kehidupan rakyatnya. Pentinganya pembangunan ekonomi bagi suatu negara dapat dilihat dari sejarah bahwa tidak ada negara yang maju secara ekonomi tanpa membina terlebih dahulu sistem industrialnya.

Pembangunan sistem industrial merupakan bagian dari pembangunan nasional yang dilakukan berdasarkan Pancasila dan Undang-Undang Dasar Negara Republik Indonesia Tahun 1945. Tujuan pembangunan sistem industrial ini tidak lain adalah meningkatkan kualitas tenaga kerja serta peningkatan perlindungan terhadap tenaga kerja dan keluarganya, serta peningkatan kesejahteraan tenaga kerja dan keluarganya 
sesuai harkat dan martabat manusia, sekaligus mempercepat laju pertumbuhan ekonomi Indonesia.

Namun sayang, lambatnya pertumbuhan ekonomi berdampak pada kehidupan masyarakat, karena pengangguran meningkat, penduduk miskin bertambah, dan lapangan kerja semakin sempit. Sementara di sisi lain, pihak pencari kerja semakin lama jumlahnya semakin banyak. Dengan demikian sumber daya manusia di Indonesia hanya unggul dalam segi kuantitas tanpa didukung keunggulan secara kualitas ${ }^{1}$. Salah faktor yang melatarbelakangi lambatnya pertumbuhan ekonomi adalah tingkat dan kualitas pendidikan seseorang yang rendah.

Kondisi demikian membawa beberapa konsekuensi yang harus ditanggung, semisal pembangunan nasional di bidang ketenagakerjaan jadi terhambat. Oleh karena itu, diperlukan adanya pembangunan dalam bidang ketenagakerjaan agar para tenaga kerja memiliki peranan dan kedudukan yang seimbang dengan pengusaha, terutama dalam hal implementasi peraturan perundang-undangan dan kesepakatan bersama. Hal ini patut menjadi catatan bersama mengingat sering kali buruh/pekerja berada di level sub-ordinat ketimbang pengusaha, meskipun secara hukum hal itu tidak dibenarkan.

Hukum bertujuan untuk mengatur dan memberikan perlindungan kepada mereka

\footnotetext{
${ }^{1}$ Djumadi, Sejarah Keberadaan Organisasi Buruh di Indonesia, Jakarta: Raja Grafindo Persada, 2005, hlm. 9.

2 UU No. 14 Tahun 2005 Tentang Guru Dan Dosen Pasal 1 angka 2 menyebutkan "Dosen adalah pendidik profesional dan ilmuwan dengan tugas utama mentransformasikan, mengembangkan,
}

yang membutuhkannya. Seorang pekerja yang bekerja pada orang lain, perusahaan atau lembaga tertentu mengharapkan suatu imbalan yang hendak dipakai untuk mencukupi kebutuhan hidupnya, begitupun juga sebaliknya. Dalam hubungan antara pekerja dan pemberi kerja tersebut dibutuhkan suatu aturan yang dapat mengatur hak dan kewajiban kedua belah pihak. Pekerja dan pemberi kerja mendapatkan perlindungan yang perlu atas hak-haknya dan sekaligus juga mempunyai kewajiban-kewajiban yang harus dijalankan.

Indonesia telah membuat peraturan tersendiri untuk mengatur tentang tenaga kerja, yaitu Undang-Undang Nomor 13 Tahun 2003 tentang Ketenagakerjaan. Dengan adanya undang-undang ini maka diharapkan hak-hak para tenaga kerja serta hal lain mengenai tenaga kerja dapat terjamin serta sejalan dengan ketentuan yang diatur dalam Pasal 27 ayat (2) UUD 1945 yang menyatakan "Tiap-tiap warga negara berhak atas pekerjaan dan penghidupan yang layak bagi kemanusiaan", serta Pasal 28D ayat (2) UUD 945 yang menyebutkan "Setiap orang berhak untuk bekerja serta mendapat imbalan dan perlakuan yang adil dan layak dalam hubungan kerja”.

Apabila mengacu pada ketentuan yang diatur dalam UUD 1945, maka dosen ${ }^{2}$, sebagai warga negara, berhak untuk bekerja serta mendapat imbalan berupa gaji ${ }^{3}$ dan perlakuan yang adil serta layak dalam

danmenyebarluaskan ilmu pengetahuan, teknologi, dan seni melalui pendidikan, penelitian, dan pengabdian kepada masyarakat".

${ }^{3}$ Peraturan Pemerintah Republik Indonesia Nomor 37 Tahun 2009 Tentang Dosen Pasal 1 Angka 6 menyebutkan "Gaji adalah hak yang diterima oleh dosen atas pekerjaannya dari penyelenggara pendidikan tinggi atau Satuan Pendidikan Tinggi 
hubungan kerja. Dosen diangkat dan ditempatkan oleh badan penyelenggara, yakni yayasan. Terkait dengan penempatan tersebut, ada hal penting yang harus dicermati oleh dosen dan tenaga kependidikan yang diangkat dan ditempatkan oleh badan penyelenggara, yakni kesepakatan yang tertuang dalam perjanjian kerja atau kesepakatan kerja sesuai dengan ketentuan peraturan perundang-undangan, khususnya Undangundang No. 13 Tahun 2003 Tentang Ketenagakerjaan ${ }^{4}$. Mengingat keduanya telah terikat dalam suatu perjanjian maka kedua pihak secara suka rela wajib untuk melaksanakan perjanjian dengan sungguhsungguh dan itikad baik.

Hubungan ketenagakerjaan yang dibangun antara dosen selaku tenaga pendidik dan badan penyelenggara pendidikan tidak bisa dilihat dari satu undang-undang saja, tetapi harus dilihat dari undang-undang lain, termasuk undangundang tentang guru dan dosen. Hal ini perlu dilakukan agar tugas pokok dan fungsi dosen dapat sejalan ketentuan yang diatur dalam peraturan perundangundangan dan tidak hanya menempatkan dosen sebagai alat produksi demi mengeruk keuntungan semata bagi perusahaan.

Apabila mengacu pada ketentuan yang diatur dalam Undang-undang No. 14 Tahun 2005 Tentang Guru dan Dosen, kedudukan tenaga pendidik sangat terhormat. Hal ini

dalam bentuk finansial secara berkala sesuai dengan peraturan perundang-undangan". Sementara itu, Undang-undang Ketenagakerjaan tidak menggunakan istilah "gaji", melainkan "upah" untuk menyebutkan imbalan. Lihat defenisi upah di Pasal 1 angka 30 UU. No.13 tahun 2003.

${ }^{4}$ Antara dosen maupun tenaga kependidikan memiliki hubungan keperdataan dengan badan penyelenggara akibatnya adanya perjanjian kerja atau kesepakatan kerja sebagaimana yang diatur dalam Pasal 1313 bisa dilihat dari ketentuan Pasal 6 Undangundang No. 14 Tahun 2005 Tentang Guru dan Dosen yang menyatakan:

"Kedudukan guru dan dosen sebagai tenaga profesional bertujuan untuk melaksanakan sistem pendidikan nasional dan mewujudkan tujuan pendidikan nasional, yaitu berkembangnya potensi peserta didik agar menjadi manusia yang beriman dan bertakwa kepada Tuhan Yang Maha Esa, berakhlak mulia, sehat, berilmu, cakap, kreatif, mandiri, serta menjadi warga Negara yang demokratis dan bertanggung jawab"6.

Ketentuan lain yang mengatur tentang kedudukan dosen sebagai tenaga professional diatur dalam Pasal 5 Undangundang No. 14 Tahun 2005 Tentang Guru dan Dosen yang menyatakan:

"Kedudukan dosen sebagai tenaga profesional sebagaimana dimaksud dalam Pasal 3 ayat (1) berfungsi untuk meningkatkan martabat dan peran dosen sebagai agen pembelajaran, pengembang ilmu pengetahuan, teknologi, dan seni, serta pengabdi kepada masyarakat berfungsi untuk meningkatkan mutu pendidikan nasional".

Buku III Kitab Undang-Undang Hukum Perdata (BW), yakni "Suatu persetujuan adalah suatu perbuatan dimana satu orang atau lebih mengikatkan diri terhadap satu orang lain atau lebih".

6 Ketentuan lebih lanjut mengenai Sistem Pendidikan Nasional dapat dilihat di Undangundang No. 20 Tahun 2003 Tentang Sistem Pendidikan Nasional. 
Demi mewujudkan tujuan dan menempatkan kedudukan dosen sebagai tenaga pendidik yang profesional, perlu upaya bersama antar semua elemen, terutama penyelenggara pendidikan. Penyelenggaraan Pendidikan tinggi sebagai bagian dari sistem pendidikan nasional tidak lepas dari peran serta masyarakat terutama dalam pengelolaannya, dimana perguruan tinggi dapat didirikan oleh masyarakat dengan membentuk badan penyelenggara berbadan hukum yang berprinsip nirlaba. Prinsip ini sekaligus memberi pemahaman bahwa dosen dan tenaga kependidikan lainnya tidak bisa diperlakukan sama dengan buruh/pekerja di sebuah perusahaan yang berorientasi pada profit (keuntungan)

Namun sayangnya, tidak semua hubungan ketenagakerjaan dapat berjalan mulus. Hal itu terlihat dari hierarki yang terjadi antara dosen dan badan penyelanggara pendidikan. Dosen masih sering terlihat berada pada posisi lemah ketimbang badan penyelenggara pendidikan. Oleh sebab itu, dosen selaku tenaga pendidik harus betul mengetahui hak dan kewajiban yang sudah diatur dan dilindungi oleh hukum.

Berdasarkan latar belakang di atas, ada beberapa permasalahan yang akan diteliti, yakni bagaimana perlindungan hukum terhadap dosen agar mendapatkan hak dan kewajiban ketenagakerjaan dan bagaimana strategi agar dosen memiliki kedudukan sederajat dengan badan penyelenggara pendidikan.

\footnotetext{
7 Beberapa undang-undang yang terkait dengan penyelenggaraan pendidikan adalah sebagai berikut:

a) Undang-undang No. 20 Tahun 2003 Tentang Sistem Pendidikan Nasional;

b) Undang-undang No. 14 Tahun 2005 Tentang Guru Dan Dosen;
}

\section{PEMBAHASAN}

\section{Perlindungan Hukum Terhadap Dosen}

1. Kedudukan Dosen Dalam Hukum

\section{Ketenagakerjaan}

Kekuatan dan semangat penyelenggaraan pendidikan semakin bertambah dengan diundangkannya berbagai peraturan perundang-undangan yang terkait dengan penyelenggaraan pendidikan ${ }^{7}$ Kemunculan peraturan perundang-undangan tersebut masih saja menimbulkan berbagai persoalan yang menjerat dunia pendidikan, meskipun sudah banyak aspek diatur di dalamnya. Salah satu persoalan yang mengemuka adalah kedudukan dosen sebagai tenaga pendidik professional yang keberadaan dan penempatannya berdasarkan perjanjian kerja antara pemberi kerja dan penerima kerja.

Ada berbagai definisi mengenai perjanjian kerja, baik yang dikemukakan oleh sarjana hukum maupun oleh peraturan perundang-undangan, di antaranya adalah:

a. Salah satu definisi tentang perjanjian kerja didefinisikan oleh Shamad, ia berpendapat bahwa "Perjanjian kerja ialah suatu perjanjian dimana seseorang mengikatkan diri untuk bekerja pada orang lain dengan imbalan berupa upah sesuai dengan syaratsyarat yang dijanjikan atau disetujui bersama";;

b. Undang-undang No. 13 Tahun 2003

Tentang Ketenagakerjaan
mendefinisikan "Perjanjian kerja

c) Undang-Undang Nomor 12 Tahun 2012 tentang Pendidikan Tinggi.

8 Abdul Khakim, Dasar-Dasar Hukum Ketenagakerjaan Indonesia, Bandung: Penerbit Citra Aditya Bakti, 2014, hlm. 49. 
adalah perjanjian antara buruh/pekerja dengan pengusaha atau pemberi kerja yang memuat syarat-syarat kerja, hak dan kewajiban para pihak";

c. Peraturan Pemerintah Republik Indonesia Nomor 37 Tahun 2009 Tentang Dosen mendefinisikan perjanjian kerja adalah sebagai berikut:

"Perjanjian kerja atau kesepakatan kerja bersama adalah perjanjian tertulis antara dosen dengan penyelenggara pendidikan tinggi atau Satuan Pendidikan Tinggi yang memuat syarat-syarat kerja serta hak dan kewajiban para pihak dengan prinsip kesetaraan dan kesejawatan berdasarkan peraturan perundangundangan".

Menurut pendapat Abdul Khakim, prinsip yang sangat menonjol dalam perjanjian kerja adalah adanya keterikatan seseorang (pekerja/buruh) kepada orang lain (pengusaha) untuk bekerja di bawah perintah dengan menerima upah'. Jadi, apabila seseorang telah mengikatkan diri dalam suatu perjanjian kerja, berarti ia secara pribadi otomatis harus bersedia bekerja di bawah perintah orang yang memberinya pekerjaan sesuai kesepakatan bersama.

Ketentuan yang diatur dalam pasal di atas mengisyaratkan adanya kedudukan

\footnotetext{
9 Ibid.

10 Subekti, Hukum Perjanjian, Jakarta: Intermasa, 1979, hlm. 13.

${ }^{11}$ Alasan bahwa pekerja/buruh memiliki kedudukan yang lebih sub-ordinat dari pengusaha dapat dilihat dari hubungan kerja yang dibangun. Berdasarkan
}

yang sama antara dsosen dan badan penyelenggara sebagai hasil dari kesepakatan antara kedua belah pihak, sebagaimana ketentuan yang diatur dalam KUHPerdata. Apapun isi yang diatur dalam perjanjian kerja antara dosen dan yayasan tergantung dari kesepakatan kedua belah pihak, sepanjang tidak bertentangan dengan peraturan perundang-undangan, kesusilaan dan ketertiban. Hal ini lazimnya disebut dengan kebebasan berkontrak ${ }^{10}$. Asas Kebebasan berkontrak diatur dalam Pasal 1338 ayat (1) BW dengan memperhatika Pasal 1320, 1335, dan 1337 BW.

Kendatipun hubungan hukum yang terbangun antara dosen dengan penyelenggara pendidikan pada hakikatnya memiliki kedudukan yang sama dalam perikatan, namun yang membedakan adalah hak dan kewajiban masing-masing pihak. Frasa "pengangkatan dan penempatan" apabila ditafsirkan secara gramatikal, maka terdapat unsur "perintah" di dalamnya atau dengan kata lain bentuk pelimpahan kewenangan karena pengusaha berhak menempatkan pekerja/buruh ditempat manapun sesuai dengan yang diinginkan oleh pengusaha. Berdasarkan hal tersebut maka kedudukan dosen terkesan tidak setara dengan badan penyelenggara dimana hubungan hukum yang dilahirkannya dalam bentuk "pemberian pekerjaan" berisi "perintah" dari pemberi kerja kepada pekerja ${ }^{11}$.

Terkait dengan kedudukan dosen dalam hukum ketenagakerjaan dapat dilihat dari

UU No. 13 Tahun 2003 Tentang Ketenagakerjaan mendefiniskan "Hubungan kerja adalah hubungan antara pengusaha dengan pekerja/buruh berdasarkan perjanjian kerja, yang mempunyai unsur pekerjaan, upah, dan perintah" 
beberapa definisi yang dikemukakan dalam Undang-undang No. 13 Tahun 2003 Tentang Ketenagakerjaan Pasal 1 angka 3 dan 4 yang menyatakan bahwa:

1. "Pekerja/buruh adalah setiap orang yang bekerja dengan menerima upah atau imbalan dalam bentuk lain;

2. Pemberi kerja adalah orang perseorangan, pengusaha, badan hukum, atau badan-badan lainnya yang mempekerjakan tenaga kerja dengan membayar upah atau imbalan dalam bentuk lain."

Ketentuan dalam pasal di atas dapat diartikan bahwa siapa saja, baik perorangan maupun kelompok, yang mengikatkan dirinya dalam suatu perjanjian kerja atau kesepakatan bersama dengan pihak lain baik perseorangan maupun badan usaha maka telah terjadi hubungan pemberi kerja dengan pekerja. Oleh karena itu, harus diakui bahwa dosen swasta sama dengan buruh/pekerja tepatnya buruh terampil.

\section{Perlindungan Hukum Terhadap} Dosen Dalam Hukum Ketenagakerjaannya

Dosen sebagai sebuah profesi memerlukan jaminan dan perlindungan melalui perundang-undangan atau tata aturan yang pasti. Hal ini sangat penting

12 Lalu Husni, Hukum Ketenagakerjaan Indonesia Edisi Revisi, Jakarta: Raja Grafindo Persada, 2010, hlm. 21. Salah satu contoh bahwa KUHPerdata bersifat liberal dapat dilihat dari Pasal 1602 yang menyebutkan "Tiada Upah yang harus dibayar untuk jangka waktu selama si buruh tidak melaksanakan pekerjaan". Pasal ini tentu akan digunakan oleh penguasa untuk berbuat sekehendaknya menafsirkan klausul "tidak melaksanakan pekerjaan". agar mereka selain memperoleh rasa aman, juga memiliki kejelasan tentang hak dan kewajibannya, apa yang boleh dan tidak boleh mereka lakukan, serta apa saja yang boleh dan tidak boleh dilakukan pihak lain kepada mereka, baik sebagai manusia, pendidik, dan pekerja. Aturan tersebut menjadi acuan bagi perjalanan hubungan kerja antara dosen selaku pekerja dengan yayasan selaku pemberi kerja, termasuk perlindungan hukumnya.

Seiring perkembangan dan dinamika kehidupan bernegara di Indonesia, peraturan mengenai perburuhan yang diatur dalam KUHPerdata dirasa lebih condong ke sifat liberal sesuai dengan falsafah negara yang membuatnya, sehingga apabila diterapkan tidak akan sesuai dengan kepribadian bangsa Indonesia ${ }^{12}$. Kondisi tersebut mengharuskan negara (Pemerintah) memberikan perlindungan hukum yang tepat kepada pekerja/buruh beserta keluarganya agar dapat memperoleh hak-hak ketenagakerjaanya yang sejalan dengan perkembangan dunia usaha $^{13}$. Atas dasar itulah muncul peraturan perundang-undangan yang terkait dengan ketenagakerjaan.

Salah satu begawan Ilmu Hukum Indonesia yang mendefiniskan "perlindungan hukum" adalah Soedikno Mertokusumo, ia berpendapat bahwa "Perlindungan hukum adalah jaminan hak dan kewajiban untuk manusia dalam

13 Lihat UU No. 13 Tahun 2003 Tentang Ketenagakerjaan diktum menimbang huruf "d" yang menyatakan "bahwa perlindungan terhadap tenaga kerja dimaksudkan untuk menjamin hak-hak dasar pekerja/buruh dan menjamin kesamaan kesempatan serta perlakuan tanpa diskriminasi atas dasar apapun untuk mewujudkan kesejahteraan pekerja/buruh dan keluarganya dengan tetap memperhatikan perkembangan kemajuan dunia usaha". 
rangka memenuhi kepentingan sendiri maupun di dalam hubungan dengan manusia"14. Sedangkan menurut Muchsin "Perlindungan hukum merupakan suatu hal yang melindungi subyek-subyek hukum melalui peraturan perundang-undangan yang berlaku dan dipaksakan pelaksanaannya dengan suatu sanksi" 15 .

Merujuk pada pendapat yang dikemukakan oleh Muchsin, ada 2 (dua) cara perlindungan hukum yang diberikan oleh negara untuk melindungi hak-hak yang dimiliki oleh warga negara, yakni:

a. Perlindungan Hukum Preventif, yakni perlindungan yang diberikan oleh pemerintah dengan tujuan untuk mencegah sebelum terjadinya pelanggaran.

Salah satu cara untuk melihat perlindungan hukum secara preventif yang diberikan oleh negara adalah dengan melihat perjanjian atau kesepakatan sebelum melakukan suatu perbuatan, termasuk perjanjian kerja yang dibuat oleh buruh/pekerja dengan pengusaha, yang akan digunakan sebagai dasar atau pijakan selanjutnya. Terkait dengan perlindungan secara preventif ini, ada hal penting lain yang harus diperhatikan, yakni eksitensi dosen sebagai tenaga pendidik yang memiliki beberapa perbedaan dengan tenaga kasar.

Berdasarkan Undang-undang No. 12 Tahun 2012 tentang Pendidikan Tinggi, maka dosen merupakan tenaga pendidik yang ditempatkan berdasarkan perjanjian. Hal ini dapat

14 Sudikno Mertokusumo, Mengenal Hukum Suatu Pengantar, Yogyakarta: Liberty, 1991, hlm. 40.

15 Muchsin, Perlindungan dan Kepastian Hukum bagi Investor di Indonesia, Surakarta: Magister ditelusuri dari ketentuan Pasal 70 ayat (2) dan (3) Undang-undang No. 12 Tahun 2012 tentang Pendidikan Tinggi yang menyatakan:

(1) Pengangkatan dan penempatan Dosen dan tenaga kependidikan oleh badan penyelenggara dilakukan berdasarkan perjanjian kerja atau kesepakatan kerja sesuai dengan ketentuan peraturan perundang-undangan;

(2) Badan penyelenggara sebagaimana dimaksud pada ayat (2) wajib memberikan gaji pokok serta tunjangan kepada Dosen dan tenaga kependidikan sesuai dengan ketentuan peraturan perundangundangan.

Sementara itu, pembahasan mengenai perjanjian kerja dapat dapat dilihat dalam Undang-undang No. 13 Tahun 2003 Tentang Ketenagakerjaan, yang teradapat dalam beberapa pasal. Pasal 52 ayat (1) menyebutkan:

(1) Perjanjian kerja dibuat atas dasar:

a) Kesepakatan kedua belah pihak;

b) Kemampuan atau kecakapan melakukan perbuatan hukum;

c) Adanya pekerjaan yang diperjanjikan; dan

d) Pekerjaan yang diperjanjikan tidak bertentangan dengan ketertiban umum, kesusilaan, dan peraturan perundangundangan yang berlaku.

Ilmu Hukum Program Pascasarjana Universitas Sebelas Maret, 2003, hlm. 20. 
Sedangkan Pasal 53 menyebutkan bahwa segala hal dan/atau biaya yang diperlukan bagi pelaksanaan pembuatan perjanjian kerja dilaksanakan oleh dan menjadi tanggung jawab pengusaha.

Ketentuan lebih lanjut mengenai perjanjian kerja dapat dilihat dalam Pasal 54 ayat (1) yang menyatakan:

(1) Perjanjian kerja yang dibuat secara tertulis sekurangkurangnya memuat:

a) Nama, alamat perusahaan, dan jenis usaha;

b) Nama, jenis kelamin, umur, dan alamat pekerja/buruh;

c) Jabatan atau jenis pekerjaan;

d) Tempat pekerjaan;

e) Besarnya upah dan cara pembayarannya;

f) Syarat-syarat kerja yang memuat hak dan kewajiban pengusaha dan pekerja/ buruh;

g) Mulai dan jangka waktu berlakunya perjanjian kerja;

h) Tempat dan tanggal perjanjian kerja dibuat; dan

i) Tanda tangan para pihak dalam perjanjian kerja.

Menurut Salim, setelah subjek hukum dalam perjanjian telah tercantum jelas bagi kedua belah pihak, termasuk mengenai kewenangan hukum masing-masing pihak, maka pembuat perjanjian harus menguasai materi atas perjanjian yang akan dibuat oleh para pihak. Dua hal paling penting dalam perjanjian adalah objek dan hakikat daripada perjanjian serta syaratsyarat atau ketentuan yang disepakati ${ }^{16}$. Menelisik ketententuan yang diatur dalam pasal di atas, maka pembahasan mengenai perlindungan hukum terhadap dosen sebagai tenaga pendidik bisa dimulai dari pemahaman tentang perjanjian kerja yang dibuat dan sekaligus menjadi hukum bagi pihak yang membuatnya (dosen dan ketua yayasan). ${ }^{17}$ Ketentuan yang diatur dalam pasal tersebut di atas harus menjadi patokan bersama untuk menentukan lebih lanjut mengenai isi perjanjian yang dibuat, sebab ketiadaan pengaturan mengenai hal-hal yang mesti ada dalam perjanjian kerja menyebabkan perjanjian tersebut menjadi cacat hukum, atau setidaktidaknya menempatkan salah satu pihak berada pada posisi lemah.

Konstruksi hukum di Indonesia menempatkan perjanjian berada dalam lingkup keperdataan, sehingga setiap perselisihan dalam hubungan keperdataan harus diselesaikan dalam ruang lingkup hukum acara perdata ${ }^{18}$, kecuali ditentukan lain dalam peraturan perundang-undangan. Berdasarkan penjelasan di atas, maka kedudukan perjanjian yang dibuat antara dosen dengan yayasan merupakan ranah hukum privat (keperdataan) yang
16 Salim H.S dkk, Perancangan Kontrak dan Memorandum of Understanding (MoU), Jakarta: Sinar grafika, 2007, hlm. 120.

17 Hal ini dilihat dalam ketentuan Pasal 1338 ayat (1) KUH Perdata yang menyatakan "semua persetujuan yang dibuat secara sah, berlaku sebagai undang-undang bagi mereka yang membuatnya".
18 Pasal 25 ayat (2) UU No. 48 Tahun 2009 Tentang Kekuasaan Kehakiman menyatakan bahwa "Peradilan umum sebagaimana dimaksud pada ayat (1) berwenang memeriksa, mengadili, dan memutus perkara pidana dan perdata sesuai dengan ketentuan peraturan perundang-undangan. 
seyogyanya dalam aspek yuridis memiliki kedudukan hukum yang sama, namun dalam aspek sosiologis hukum ternyata kedudukan dosen tidak sederajat. Oleh sebab itu, kewajiban pemerintah untuk campur tangan dalam mengatur dan melindungi pekerja (dosen swasta) dari tindakan semenamena yayasan dalam pelaksanaan perjanjian kerja, penentuan upah minimum, Pemutusan Hubungan Kerja (PHK) dan lain sebagainya ${ }^{19}$.

b. Perlindungan Hukum Represif, yakni perlindungan akhir berupa sanksi $^{20}$ yang diberikan apabila sudah terjadi sengketa atau telah dilakukan suatu pelanggaran

Meski telah ada peraturan perundang-undangan dan perjanjian kerja, namun masih sering ditemui perselisihan hubungan industrial antara buruh/pekerja dengan pengusaha. Hal itu tidak hanya berlaku pada buruh/pekerja yang bekerja di perusahaan, melainkan merambah juga

19 Meskipun hubungan hukum yang dibuat antara dosen dengan yayasan berisfat privat (keperdataan), namun Negara memiliki peran penting untuk menjaga agar dalam hubungan kerja yang dibangun tidak menimbulkan kesewenang-wenangan oleh pihak yang kuat terhadap pihak yang lemah. Salah satu keterlibatan pemerintah dapat dilihat dari penentuan "kebutuhan Hidup Layak" dengan mendirikan "Dewan Pengupahan, sebagaimana diatur dalam Peraturan Menteri Tenaga Kerja Dan Transmigrasi Republik Indonesia Nomor 13 Tahun 2012 Tentang Komponen Dan Pelaksanaan Tahapan Pencapaian Kebutuhan Hidup Layak .

${ }^{20}$ Menurut Achmad Ali, sanksi memuat beberapa unsur, yakni:

1) Sanksi merupakan reaksi, akibat, atau konsekuensi dari pelanggaran atau penyimpangan kaidah sosial (baik kaidah hukum maupun kaidah non hukum);

2) Sanksi merupakan kekuasaan atau alat kekuasaan untuk memaksakan ditaatinya kaidah sosial tertentu; di sektor pendidikan, terutama di sektor yang menempatkan badan penyelenggara pendidikan sebagai lahan untuk berbisnis ${ }^{21}$. Perselisihan di bidang hubungan industrial yang selama ini dikenal dapat terjadi mengenai hak yang telah ditetapkan, atau mengenai keadaan ketenagakerjaan yang belum ditetapkan baik dalam perjanjian kerja, peraturan perusahaan, perjanjian kerja bersama maupun peraturan perundangundangan $^{22}$.

Bahkan pada tataran yang lebih teknis telah ada perjanjian kerja yang dilakukan oleh dosen dan yayasan. Namun, tidak serta merta persoalan tersebut selesai. Ada berbagai konflik yang mengiringi perjalanan pelaksanaan perjanjian kerja. Oleh sebab itu, perlindungan hukum sebagai suatu gambaran tersendiri dari fungsi hukum yang memiliki konsep bahwa hukum memberikan suatu keadilan, ketertiban, kepastian, kemanfaatan dan kedamaian, terutama kepada pihak-

3) Khusus mengenai sanksi hukum, pada garis besarnya dapat dibedakan atas:

a) Sanksi privat; dan

b) Sanksi publik.

Lihat Achmad Ali, Menguak Tabir Hukum Edisi Kedua, Jakarta: Kencana, hlm. 63-64.

21 UU No. 28 Tahun 2004 Tentang Perubahan Atas Undang-Undang Nomor 16 Tahun 2001 Pasal 1 angka 1 menyatakan "Yayasan adalah badan hukum yang terdiri atas kekayaan yang dipisahkan dan diperuntukkan untuk mencapai tujuan tertentu di bidang sosial, keagamaan, dan kemanusiaan yang tidak mempunyai anggota". Merujuk pada definisi yang dikemukakan oleh undang-undang tersebut, sudah seharusnya badan penyelenggara pendidikan tidak berorientasi pada keuntungan atau profit.

22 Lihat Penjelasan Undang-Undang Republik Indonesia Nomor 2 Tahun 2004 Tentang Penyelesaian Perselisihan Hubungan Industrial bagian Umum. 
pihak yang potensial untuk dilanggar hak-haknya, atau kepada mereka yang posisinya lemah.

Terkait dengan konflik yang terjadi antara dosen dan yayasan, hukum menempatkan diri pada posisi "penyelesai konflik". Undang-undang No. Nomor 2 Tahun 2004 Tentang Penyelesaian Perselisihan Hubungan Industrial memberikan jalan penyelesain perselisihan hubungan industrial melalui 2 (dua) mekanisme, yakni:

a. Mekanisme penyelesaian di luar pengadilan.

Penyelesaian

perselisihan

Hubungan Industrial ${ }^{23}$ diatur dalam Undang-undang No. 2 Tahun 2004 Tentang Penyelesaian Perselisihan Hubungan Industrial memungkinkan penyelesaian sengketa buruh/tenaga kerja di luar pengadilan. Ketentuan tersebut bisa dilihat dalam Pasal 3 ayat (1) yang berbunyi "Perselisihan hubungan industrial wajib diupayakan penyelesaiannya terlebih dahulu

23 UU No. 2 Tahun 2004 Tentang Penyelesaian Perselisihan Hubungan Industrial Pasal 1 Angka 1 menyatakan:

"Perselisihan Hubungan Industrial adalah perbedaan pendapat yang mengakibatkan pertentangan antara pengusaha atau gabungan pengusaha dengan pekerja/buruh atau serikat pekerja/serikat buruh karena adanya perselisihan mengenai hak, perselisihan kepentingan, perselisihan pemutusan hubungan kerja dan perselisihan antar serikat pekerja/serikat buruh dalam satu perusahaan".

${ }^{24}$ Pasal 1 angka 10 Undang-undang Nomor 2 Tahun 2004 tentang Penyelesaian Perselisihan Hubungan Industrial menyatakan "Perundingan bipartit adalah perundingan antara pekerja/buruh atau serikat pekerja/serikat buruh dengan pengusaha untuk menyelesaikan perselisihan hubungan industrial" melalui perundingan bipartit $^{24}$ secara musyawarah untuk mencapai mufakat".

Pasal tersebut memberi jalan penyelesaian sengketa antara buruh/pekerja dan pengusaha berdasarkan musyawarah mufakat dengan mengadakan azas kekeluargaan. Apabila terdapat kesepakatan antara buruh dan majikan atau antara serikat pekerja dengan majikan, maka harus dituangkan dalam perjanjian kesepakatan kedua belah pihak yang disebut dengan perjanjian bersama dengan ketentuan bahwa perjanjian yang disepakati oleh kedua belah pihak mengikat secara hukum serta wajib dilaksanakan ${ }^{25}$.

Penyelesaian melalui musyawarah atau di luar pengadilan merupakan penyelesaain tahap awal dengan harapan perselisihan yang terjadi dapat ditemukan solusinya ${ }^{26}$. Namun sayangnya, dalam proses musyawarah tidak serta merta menghasilkan kesepatakan bersama. Hal itu terjadi karena masing-masing pihak mempertahankan pendapat dan keyakinannya sendiri, sehingga kata

25 Undang-undang Nomor 2 Tahun 2004 tentang Penyelesaian Perselisihan Hubungan Industrial Pasal 7 menyatakan:

(1) Dalam hal musyawarah sebagaimana dimaksud dalam Pasal 3 dapat mencapai kesepakatan penyelesaian, maka dibuat Perjanjian Bersama yang ditandatangani oleh para pihak.

(2) Perjanjian Bersama sebagaimana dimaksud pada ayat (1) mengikat dan menjadi hukum serta wajib dilaksanakan oleh para pihak.

26 Penyelesaian di luar pengadilan dilakukan dengan beberapa cara, yakni:

1) Perundingan Bipartit;

2) Mediasi;

3) Konsiliasi;

4) Arbitase. 
"sepakat" tidak pernah terwujud dalam musyawarah tersebut. Maka, tidak ada jalan lain yang bisa ditempuh oleh kedua belah pihak selain melalui jalur hukum.

Sebagai negara hukum, Indonesia harus menciptakan suatu sistem penegakan hukum yang mampu mewujudkan harmoni, kedamaian, ketertiban dan kesejahteraan bagi masyarakat. Dalam pandangan hukum progresif, sistem penegakan hukum yang demikian merupakan sistem penegakan hukum yang pro rakyat, membebaskan dan membahagiakan masyarakat ${ }^{27}$ Oleh sebab itu, mekanisme selanjutnya yang bisa ditempuh oleh dosen apabila terjadi perselisihan ketenagakerjaan dengan pihak yayasan adalah melalui mekanisme hukum, yakni Pengadilan Hubungan Industrial.

\section{b. Penyelesaian melalui jalur pengadilan \\ Hukum baru beroperasi setelah} adanya suatu konflik. Ia beroperasi melalui lembaga pengadilan. Dalam hal seperti ini, menjadi tugas pengadilan untuk menjatuhkan suatu putusan yang menyelesaikan konflik tersebut. Parsons dan rekan-rekannya melihat

27 Bambang Waluyo, Penegakan Hukum di Indonesia, Jakarta: Sinar Grafika, 2016, hlm. 136. 28 Achmad Ali, Op. Cit, hlm. 118.

29 Secara normatif, kompetensi absolut yang dimiliki oleh Pengadilan Hubungan Industrial terlihat dalam Pasal 56, yang menyatakan:

"Pengadilan Hubungan Industrial bertugas dan berwenang memeriksa dan memutus:

a) di tingkat pertama mengenai perselisihan hak;

b) di tingkat pertama dan terakhir mengenai perselisihan kepentingan; bahwa pengadilan bergantung pada 3 (tiga) jenis masukan, yaitu ${ }^{28}$ :

1) "Pengadilan membutuhkan suatu analisis mengenal sebab dan akibat dari peristiwa yang dipersengketakan itu;

2) Pengadilan membutuhkan suatu konsepsi tentang pembagian tugas: apa yang menjadi tujuan dari sistem itu, keadaan apa yang ditimbulkan oleh penggunaan kekuasaan;

3) Pengadilan menghendaki agar penggugat memilih pengadilan sebagai mekanisme penyelesaian konflik".

Guna mengantisipasi penyelesaian dan penyaluran sengketa ketenagakerjaan agar sejalan dengan tuntutan kemajuan zaman, maka dibuat dan diundangkan Undang-undang Nomor 2 Tahun 2004 Tentang Penyelesaian Perselisihan Hubungan Industrial sebagai wadah Peradilan Hubungan Industrial (PHI) di lingkup peradilan umum. ${ }^{29}$ Kehadiran Undangundang ini sekaligus menegaskan bahwa peraturan perundang-undangan sebelumnya, yang mengatur tentang penyelesaian perselisihan hubungan industrial, masih belum mewujudkan

c) di tingkat pertama mengenai perselisihan pemutusan hubungan kerja;

d) di tingkat pertama dan terakhir mengenai perselisihan antar serikat pekerja/serikat buruh dalam satu perusahaan".

Ketentuan tersebut dilanjutkan dalam Pasal 57 yang menyebutkan Hukum Acara yang dipakai dalam Penyelsaian Hubungan Industrial adalah Hukum Acara Perdata, kecuali ditentukan lain oleh peraturan perundang-undangan. 
penyelesaian yang cepat, adil, dan murah.

Demi mewujudkan penyelesaian yang cepat, tepat, adil dan murah, penyelesaian perselisihan hubungan industrial melalui Pengadilan Hubungan Industrial (PHI) dibatasi proses dan tahapannya dengan tidak membuka kesempatan untuk mengajukan upaya banding ke Pengadilan Tinggi, Putusan Pengadilan Hubungan Industrial pada Pengadilan Negeri yang menyangkut perselisihan hak dan perselisihan pemutusan hubungan kerja dapat langsung dimintakan kasasi ke Mahkamah Agung. Sedangkan putusan Pengadilan Hubungan Industrial pada Pengadilan Negeri yang menyangkut perselisihan kepentingan dan perselisihan antar serikat pekerja/serikat buruh dalam satu perusahaan merupakan putusan tingkat pertama dan terakhir yang tidak dapat di mintakan kasasi ke Mahkamah Agung $^{30}$.

Perselisihan yang timbul sebagai akibat dari adanya hubungan kerja tidak hanya berkutat pada kasus yang

\footnotetext{
${ }^{30}$ Penjelasan Undang-Undang Republik Indonesia Nomor 2 Tahun 2004 Tentang Penyelesaian Perselisihan Hubungan Industrial Dalam Kententuan Umum Nomor. 10.

31 Salah satu contoh kasusnya adalah Putusan majelis hakim Pengadilan Negeri Bangil, Jawa Timur, menghukum seorang pengusaha mebel satu tahun penjara. Pengusaha tersebut dinyatakan terbukti melakukan tindak pidana perburuhan dengan membayar rendah upah buruhnya dan menghalang-halangi buruhnya untuk berserikat. Selain penjara, si pengusaha juga dihukum denda sebesar Rp250 juta.

32 Berdasarkan UU No. 28 Tahun 2004 Tentang Perubahan Atas Undang-Undang Nomor 16 Tahun 2001 Tentang Yayasan Pasal 1 Menyebutkan Bahwa Yayasan adalah Badan Hukum. Konsekuensi hukum dari yayasan sebagai badan
}

menjadi wewenang Pengadilan Hubungan Industrial semata, namun berbagai persoalan lain tidak luput mendera dosen, salah satunya adalah tindak pidana yang dilakukan oleh pihak yayasan kepada dosen. Salah satu bentuk tindak pidana yang sering dilakukan oleh pengusaha kepada pekerja/buruh adalah membayar upah buruh lebih rendah dari upah minimum dan menghalang-halangi buruh untuk membentuk serikat ${ }^{31}$.

Pengaturan tentang tindak pidana ketenagakerjaan dapat dilihat dalam ketentuan Pasal 183 sampai dengan 189 Undang-undang No. 13 Tahun 2003 Tentang Ketenagakerjaan. Ketentuan ini memberikan hak kepada dosen untuk melaporkan tindak pidana yang dilakukan oleh yayasan kepada pihak kepolisian apabila ada ketentuan tindak pidana yang dilanggar, sampai pada pemeriksaan level selanjutnya, yakni putusan Pengadilan Negeri. Namun, secara teknis ada banyak hal yang perlu diselesaikan apabila pengusaha tersebut berkedudukan sebagai badan hukum ${ }^{32}$.

hukum adalah ia berkedudukan sebagai subyek hukum. Menurut Satjipto Rahardjo, penempatan korporasi sebagai sebagai subyek hukum dalam hukum pidana tidak lepas dari modernisasi sosial yang berdampak pada harus diakuinya kehidupan masyarakat yang semakin modern semakin kompleks sistem sosial, ekonomi dan politik, sehingga kebutuhan akan sistem pengendalian kehidupan yang formal akan menjadi semakin besar pula. Lihat Muladi dan Dwidja Priyatno, Pertangungjawaban Pidana Korporasi Edisi Revisi, Cetakan ke-4, Jakarta: Kencana, 2013, hlm. 43. Di samping itu, Mardjono Reksodipuro mengatakan bahwa dalam perkembangan hukum pidana di Indonesia ada 3 (tiga) sistem pertanggungjawaban korporasi sebagai subyek tindak pidana, yaitu: 
Strategi Agar Dosen Memiliki Posisi Sama Dengan Badan Penyelenggara Pendidikan

Ketentuan dalam peraturan perundangundangan menempatkan para pihak memiliki kedudukan sederajad dalam suatu perjanjian. Namun, pada tataran pelaksanaannya masih ada beberapa kasus yang pemberlakuannya belum sesuai dengan peraturan perundang-undangan dan kesepakatan bersama. Hal ini terjadi karena nilai tawar buruh/pekerja rendah di mata pengusaha, sekaligus kenyataan bahwa jumlah tenaga kerja dengan lapangan pekerjaan yang tersedia masih belum sebanding, sehingga memunculkan pemahaman bahwa pengusaha dengan seenaknya memperlakukan buruh/pekerja karena masih banyak tenaga kerja yang menggantikan apabila buruh/pekerja tersebut diberhentikan.

Ketakutan terbesar bagi perusahaan adalah ketika "permainan mulus" mereka mempekerjakan pekerja/buruh tidak sesuai dengan ketentuan peraturan perundangundangan diketahui oleh publik, seperti membayar upah di bawah UMK, tidak memberikan jaminan kesehatan, memberikan lembur yang tidak layak bayar, mengharuskan pekerja (dosen) bekerja melebih jam yang telah ditetapkan

Pengurus korporasi sebagai pembuat, maka penguruslah yang bertanggung jawab; korporasi sebagai pembuat, maka korporasilah yang bertanggung jawab; dan korporasi sebagai pembuat dan penanggungjawab. Lihat Mahrus Ali, Kejahatan Korporasi Kajian Relevansi Sanksi Tindakan Bagi Penanggulangan Kejahatan Korporasi, Yogyakarta: Arti Bumi Intaran, 2008, hlm. 47.

\footnotetext{
${ }^{33}$ Pasal 28 menyatakan:

"Siapapun dilarang menghalang-halangi atau memaksa pekerja/buruh untuk membentuk atau
}

berdasarkan undang-undang yang berlaku dengan dalih loyalitas, dan sebagainya. Kondisi demikian memicu "perlawanan" dari buruh/pekerja (dosen), meskipun dengan skala yang kurang massif. Maka, tidak mengherankan bila sebagian perusahaan berupaya untuk menghalanghalangi buruh/pekerja menggalang kekuatan.

Kedudukan buruh yang lemah ini membutuhkan suatu pilar penyangga untuk memperkuat perjuangan guna memperoleh hak-haknya. Ada beberapa pilar yang sangat berperan menegakkan hak-hak pekerja atau buruh untuk mewujudkan kesejahteraannya, salah satunya melalui organisasi serikat pekerja/serikat buruh yang bertujuan untuk menyeimbangkan posisi buruh dengan pengusaha. Eksistensi serikat ini seperti ungkapan "sebatang sapu lidi, ketika bersatu, susah dipatahkan, tapi kalau sendiri, mudah dipatahkan". Kedudukan serikat pekerja/buruh ini didukung dengan adanya perlindungan hak berorganisasi yang diatur dalam oleh Undang-undang No. 21 Tahun 2000 Tentang Serikat Pekerja/Serikat Buruh ${ }^{33}$.

Jaminan konstitusional berserikat diatur dalam Undang-Undang Dasar (UUD) 1945 Pasal 28E ayat (3) yang menyatakan "Setiap orang berhak atas

tidak membentuk,menjadi pengurus atau tidak menjadi pengurus, menjadi anggota atau tidak menjadi anggota dan/ataumenjalankan atau tidak menjalankan kegiatan serikat pekerja/serikat buruh dengan cara:

a) Melakukan pemutusan hubungan kerja, memberhentikan sementara, menurunkan jabatan, atau melakukan mutasi;

b) Tidak membayar atau mengurangi upah pekerja/buruh;

c) Melakukan intimidasi dalam bentuk apapun;

d) Melakukan kampanye anti pembentukan serikat pekerja/serikat buruh". 
kebebasan berserikat, berkumpul, dan mengeluarkan pendapat”. UUD 1945 secara langsung dan tegas memberikan jaminan kebebasan untuk berserikat atau berorganisasi, kebebasan berkumpul, dan kebebasan menyatakan pendapat, tidak hanya bagi setiap warga negara Indonesia, termasuk terbentuknya serikat buruh/pekerja. Jaminan berserikat ini tidak hanya sebatas jaminan hukum semata, namun juga merupakan bentuk Hak Asasi Manusia (HAM) ${ }^{34}$.

Pengertian serikat buruh/pekerja dapat kita lihat dalam ketentuan Undang-undang No. 21 Tahun 2000 Tentang Serikat Pekerja/Serikat Buruh Pasal 1 Angka 1 yang menyebutkan:

"Serikat pekerja/serikat buruh adalah organisasi yang dibentuk dari, oleh, dan untuk pekerja/buruh baik di perusahaan maupun di luar perusahaan, yang bersifat bebas, terbuka, mandiri, demokratis, dan bertanggung jawab guna memperjuangkan, membela serta melindungi hak dan kepentingan pekerja/buruh serta meningkatkan kesejahteraan pekerja/buruh dan keluarganya".

Kebebasan dosen membentuk serikat juga diperkuat dengan ketentuan Peraturan Pemerintah Nomor 37 Tahun 2009 Tentang Dosen Pasal 30 yang menyatakan:

“(1) Dosen memiliki kebebasan untuk berserikat dalam organisasi profesi atau organisasi profesi keilmuan

\footnotetext{
34 Pasal 24 ayat (1) Undang-Undang Nomor 39 Tahun 1999 Tentang Hak Asasi Manusia menyatakan: "Setiap orang berhak untuk berkumpul, berapat, dan berserikat untuk maksudmaksud yang damai".

${ }^{35}$ Jimly Asshiddiqie, "Mengatur Kebebasan Berserikat Dalam Undang-Undang", diakses dari http://jimlyschool.com/read/analisis/274/mengatur-
}

sesuai dengan ketentuan peraturan perundangundangan.

(2) Kebebasan untuk berserikat sebagaimana dimaksud pada ayat (1) tidak mengganggu pelaksanaan tridharma perguruan tinggi yang menjadi tanggungjawab keprofesionalan".

Setiap orang bebas membentuk atau ikut serta dalam keanggotaan atau menjadi pengurus organisasi dalam kehidupan bermasyarakat dalam wilayah negara Republik Indonesia. Hanya saja, bagaimana kebebasan itu digunakan, apa saja syarat-syarat dan prosedur pembentukan, pembinaan, penyelenggaraan kegiatan, pengawasan, dan pembubaran organisasi itu tentu masih harus diatur lebih rinci, yaitu dengan undang-undang beserta peraturan pelaksanaannya. $^{35}$ Dengan kata lain, ketentuan yang tercantum dalam suatu peraturan perundang-undangan yang terkait dengan serikat pekerja/buruh hakikatnya adalah memberi batasan antara mana yang boleh dilakukan dan mana yang tidak boleh dilakukan oleh serikat pekerja/serikat buruh.

Pada prinsipnya, kebebasan berserikat yang dijamin oleh peraturan perundangundangan memiliki 2 (dua) tujuan pokok yang harus dicapai, yakni: Pertama, hak asasi manusia harus dilindungi sebagai hak dasar; Kedua, harus ada jaminan bahwa hak dan kebebasan orang lain dapat terlaksana

kebebasan-berserikat-dalam-undangundang/ pada tanggal 5 November 2016 pukul 17.30. Pengaturan mengenai materi atau persoalan yang digariskan oleh ketentuan-ketentuan hukum yang menjadi dasar diterbitkannya peraturan yang lebih rendah atau lebih khusus lazimnya disebut dengan peraturan perundang-undangan organik. 
dengan baik. Agar tujuan tersebut dapat diwujudkan, maka hak atas kebebasan berserikat dibatasi oleh dua klausa yaitu kepentingan umum dan peraturan perundang-undangan yang berlaku ${ }^{36}$. Pembatasan tersebut dalam rangka memberi perlindungan bagi pihak lain dari bentuk kesewenang-wenangan serikat pekerja/serikat buruh.

Serikat pekerja merupakan sarana kanalisasi untuk menyampaikan hasrat, harapan, keluhan, saran atau kritik pekerja terhadap pengusaha. Dalam sistem manajemen modern, sangat ditekankan pentingnya pendekatan kemanusiaan untuk menumbuhkan motivasi pekerja. Selain itu jalur-jalur semi formal dan jalur non formal yang ada di perusahaan merupakan mekanisme yang sangat efektif melebihi jalur struktural yang hirarkis. Dalam hal ini serikat pekerja berfungsi sebagai jalur semi formal. Melalui serikat pekerja, harapan, petunjuk dan informasi dari perusahaan dapat disampaikan dengan baik kepada pekerja $^{37}$.

Di samping itu, manfaat membentuk serikat pekerja ataupun ikut tergabung menjadi anggota serikat pekerja/buruh, terutama yang berkaitan atau bersentuhan langsung dengan keadaan pekerja/buruh, antara lain ${ }^{38}$ :

a. Menjalin komunikasi antara pekerja/buruh dengan pekerja/buruh yang notabene memiliki kesamaan kepentingan dan kesamaan hak;

36 Bahder Johan Nasution, Hukum Ketenagakerjaan Kebebasan Berserikat Bagi Pekerja, Bandung: Mandar Maju, 2004, hlm 44.

37 Bahder Johan Nasution, "Fungsi Kebebasan Berserikat Bagi Pekerja Dalam Hubungan Industrial Pancasila", Jurnal Inovatif, Volume VIII, Nomor I, 2015, hlm. 4-5. b. Mendapatkan advokasi atau pembelaan dari persoalan yang merugikan pekerja jika pengusaha atau pimpinanan melakukan tindakan yang tidak sesuai dengan aturan ketenagakerjaan yang telah diatur di dalam peraturan perundang-undangan;

c. Bergerak secara bersama untuk memperjuangkan kepentingan atau hak pekerja/buruh akan lebih mudah tercapai;

d. Memudahkan pekerja/buruh dalam hal komunikasi ke pengusaha/pimpinan perusahaan, karena ada pengurus Serikat Pekerja/buruh yang akan mengakomodir kepentingan sesuai dengan aturan perundangundangan.

Sedangkan fungsi serikat pekerja/serikat buruh menurut ketentuan yang diatur dalam Undang-undang No. 21 Tahun $2000 \quad$ Tentang Serikat Pekerja/Serikat Buruh dapat dilihat dalam Pasal 4 yang menyatakan:

“(1) Serikat pekerja/serikat buruh, federasi dan konfederasi serikat pekerja/serikat buruh bertujuan memberikan perlindungan, pembelaan hak dan kepentingan, serta meningkatkan kesejahteraan yang layak bagi pekerja/buruh dan keluarganya.

38 DPC. KSPSI Kab. Tengerang, Manfaat dan Pentingnya Berserikat, diakses melalui http://kspsitangerang.blogspot.co.id/2015/02/manfa at-dan-pentingnya-berserikat.html pada tanggal 7 November 2016, diakses pukul 16.05. 
(2) Untuk mencapai tujuan sebagaimana dimaksud dalam ayat (1) serikat pekerja/serikat buruh, federasi dan konfederasi serikat pekerja/serikat buruh mempunyai fungsi:

a. Sebagai pihak dalam pembuatan perjanjian kerja bersama dan penyelesaian perselisihan industrial;

b. Sebagai wakil pekerja /buruh dalam lembaga kerja sama di bidang ketenagakerjaan sesuai dengan tingkatannya;

c. Sebagai sarana menciptakan hubungan industrial yang harmonis, dinamis, dan berkeadilan sesuai dengan peraturan perundangundangan yang berlaku;

d. Sebagai sarana penyalur aspirasi dalam memperjuangkan hak dan kepentingan anggotanya;

e. Sebagai perencana, pelaksana, dan penanggung jawab pemogokan pekerja/buruh sesuai dengan peraturan perundang-undangan yang berlaku;

f. Sebagai pekerja/buruh dalam memperjuangkan kepemilikan saham di perusahaan.

Serikat pekerja sebagai lembaga atau organisasi yang menaungi buruh/pekerja, baik di dalam perusahaan maupun di luar perusahaan, memiliki beberapa hak yang dilindungi oleh undang-undang. Hak tersebut dapat dilihat dalam ketentuan Pasal 25 ayat (1) Undang-undang No. 21 Tahun 2000 Tentang Serikat Pekerja/Serikat Buruh yang menyatakan:

"Serikat pekerja/serikat buruh, federasi dan konfederasi serikat pekerja/serikat buruh yang telah mempunyai nomor bukti pencatatan berhak:

a) Membuat perjanjian kerja bersama dengan pengusaha;

b) Mewakili pekerja/buruh dalam menyelesaikan perselisihan industrial;

c) Mewakili pekerja/buruh dalam lembaga ketenagakerjaan;

d) Membentuk lembaga atau melakukan kegiatan yang berkaitan dengan usaha peningkatan kesejahteraan pekerja/buruh;

e) Melakukan kegiatan lainnya di bidang ketenagakerjaan yang tidak bertentangan dengan peraturan perundang-undangan yang berlaku".

Eksistensi serikat pekerja/buruh di masa sekarang ini sedikit demi sedikit menunjukkan posisi yang lebih elegan di mata hukum, sebab keberadaanya tidak hanya berbicara bagaimana buruh/pekerja memperjuangkan hak-hak mereka melalui jalan kekerasan, akan tetapi semakin cerdas memperjuangkan hak-haknya melalui ilmu, dialog, dan keterlibatan media massa. Caracara semacam ini lebih mudah mendapatkan respon dari pengusaha, 
sekaligus menutup ruang terbukanya kesempatan bagi pengusaha untuk menuntut balik serikat buruh/pekerja sebagai akibat dari tindakan melawan hukum yang dilakukan oleh para pekerja yang cenderung represif.

Undang-undang sudah jelas mengamanatkan kepada perusahan, dalam hal ini yayasan yang menaungi badan penyelenggara pendidikan, untuk tidak menghalang-halangi dosen membentuk serikat pekerja/buruh. Namun sayangnya hingga saat ini masih sangat jarang ditemukan adanya serikat pekerja dosen yang tergabung di badan penyelenggara pendidikan. Hal itu bisa saja terjadi karena serikat dosen masih belum familiar di Indonesia. Padahal, menilisik dari pemahaman dan pengetahuan yang dimiliki oleh seorang dosen, tentu serikat dosen yang dibentuk oleh para dosen dan/atau tenaga kependidikan lebih mudah melakukan aksi-aksi yang elegan, sejalan dengan koridor hukum, serta memiliki tingkat keberhasilan lebih besar.

\section{PENUTUP}

Dosen memiliki kedudukan yang sederajat dengan yayasan sesuai dengan perjanjian kerja yang dilakukan oleh kedua belah pihak. Perlindungan hukum yang diberikan kepada dosen dapat dilihat dari 2 (dua) cara, yakni: Pertama, Preventif melalui perjanjian yang dibuat sebelum dosen tersebut bekerja di universitas; Kedua, Represif melalui lembaga Pengadilan Hubungan Industrial (PHI).

Strategi agar dosen memiliki kedudukan yang sederajat secara sosiologis adalah dengan membentuk serikat buruh/pekerja. Serikat buruh/pekerja memiliki banyak manfaat dan tujuan, bahkan eksistensi serikat buruh/pekerja dilindungi oleh peraturan perundang-undangan, bahkan menghalang-halangi buruh/pekerja membentuk serikat pekerja/buruh merupakan tindak pidana ketenagakerjaan.

Dalam penelitian ini, penulis juga menyarankan, kendaknya dosen membentuk serikat pekerja/serikat buruh agar pengusaha (pihak yayasan) tidak berbuat sekehendaknya sendiri.

\section{DAFTAR PUSTAKA}

\section{Buku}

Abdul Khakim, Dasar-Dasar Hukum Ketenagakerjaan Indonesia, Bandung: Penerbit PT Citra Aditya Bakti, 2014 Achmad Ali, Menguak Tabir Hukum Edisi Kedua, Jakarta: Kencana, 2015 Bambang Waluyo, Penegakan Hukum di Indonesia, Jakarta: Sinar Grafika, 2016 Bahder Johan Nasution, Hukum Ketenagakerjaan Kebebasan

Berserikat Bagi Pekerja, Bandung: Mandar Maju, 2004

Djumadi, Sejarah Keberadaan Organisasi Buruh di Indonesia, Jakarta: RajaGrafindo Persada, 2005

Lalu Husni, Hukum Ketenagakerjaan Indonesia Edisi Revisi, Jakarta: RajaGrafindo Persada, 2010

Mahrus Ali, Kejahatan Korporasi Kajian

Relevansi Sanksi Tindakan Bagi Penanggulangan Kejahatan Korporasi, Yogyakarta: Arti Bumi Intaran, 2008 Muchsin, Perlindungan dan Kepastian Hukum bagi Investor di Indonesia, Surakarta: Magister Ilmu Hukum Program Pascasarjana Universitas Sebelas Maret, 2003

Muladi dan Dwidja Priyatno, Pertangungjawaban Pidana Korporasi 
Edisi Revisi, Cetakan ke-4, Jakarta: Kencana, 2013

Salim H.S dkk, Perancangan Kontrak dan Memorandum of Understanding (MoU), Jakarta: Sinar grafika, 2007

Subekti, Hukum Perjanjian, Jakarta: Intermasa, 1979

Sudikno Mertokusumo, Mengenal Hukum Suatu Pengantar, Yogyakarta: Liberty, 1991

\section{Peraturan Perundang-undangan}

Undang-Undang Dasar Negara Republik Indonesia 1945

KUH Perdata

Undang-Undang Nomor 39 Tahun 1999 Tentang Hak Asasi Manusia

Undang-undang No. 21 Tahun 2000 Tentang Serikat Pekerja/Serikat Buruh

Undang-undang No. 13 Tahun 2003 Tentang Ketenagakerjaan

Undang-undang No. 2 Tahun 2004 Tentang Penyelesaian Perselisihan Hubungan Industrial

Undang-undang No. 28 Tahun 2004 Tentang Perubahan Atas UndangUndang Nomor 16 Tahun 2001 Tentang Yayasan

Undang-undang No. 14 Tahun 2005 Tentang Guru Dan Dosen.

Undang-undang No. 48 Tahun 2009

Tentang Kekuasaan Kehakiman

Peraturan Pemerintah No. 37 Tahun 2009

Tentang Dosen

\section{Jurnal}

Bahder Johan Nasution, "Fungsi Kebebasan Berserikat Bagi Pekerja Dalam Hubungan Industrial Pancasila”, Jurnal Inovatif, Volume VIII, Nomor I, 2015.

\section{Internet}

Jimly Asshiddiqie, Mengatur Kebebasan Berserikat Dalam Undang-Undang, diakses dari http://jimlyschool.com/read/analisis/27 4/mengatur-kebebasan-berserikatdalam-undangundang/ pada tanggal 5 November 2016 pukul 17.30.

DPC. KSPSI Kab. Tengerang, Manfaat dan Pentingnya Berserikat, diakses melalui http://kspsitangerang.blogspot.co.id/20 15/02/manfaat-dan-pentingnyaberserikat.html pada tanggal 7 November 2016 pukul 16.05 